Research in Social Sciences

\section{ISSN: 2641-5305}

Vol. 4, No. 1, pp. 8-15

2021

DOI: $10.53935 / 2641-5305 . v 4 i 1.61$

(C) 2021 by the authors; licensee Academic Publishing Group

\title{
Analyzing the Effects of CLIL Method in Teaching Business English Writing in China
}

He Rong: PhD Student, Faculty of Education and Liberal Studies, City University Malaysia, Petaling Jaya, Selangor, Malaysia.

-Subadrah Madhawa Nair: Lecturer, Faculty of Education and Liberal Studies, City University Malaysia, Petaling Jaya, Selangor, Malaysia.

\begin{abstract}
The use of CLIL (Content and Language Integrated Learning) teaching method in English writing proved to be efficient in enhancing students' language and content knowledge. This study aims to explore the effects of utilizing CLIL method in teaching Business English Writing among Chinese college students. A quasi-experimental design was adopted. The experiment lasted for a total of eight weeks. The Experimental Group was taught Business English Writing using CLIL method while the Control Group was instructed with the conventional method. The sample of the study consists of 80 third year Business English college students from Shaoyang University in Hunan Province, China. Two classes of students were chosen as intact group sampling (40 students in each group). A pre-test and post-test were used as instruments. The data was analyzed using Independent samples t-test. Prior to the actual study a pilot test was carried out to obtain the reliability and validity of the instrument (writing test). The findings from quantitative data showed that students of the Experimental Group using CLIL teaching method performed significantly higher in their overall Business English Writing, report writing, memo writing, letter writing than students in the Control Group using conventional method. Therefore, it can be concluded that the CLIL principle should be employed as an alternative method in future writing classes. These findings have significant pedagogical implications because the CLIL method facilitated students to improve in their Business English writing skills.
\end{abstract}

Key words: CLIL method, Conventional method, Business English Writing, Report writing, Memo writing, Letter writing.

\section{Introduction}

With the advent of globalization, international exchanges and cooperation have made college graduates with professional business knowledge and English writing and speaking skills urgently needed by society (Andon \& O'Riordan, 2004; Pavlenko \& Norton, 2007). However, college students' English level in China is increasingly unable to meet the requirement of the global market (Wen, 2012). Business English writing skills plays an important role in modern business activities because of its convenience and efficiency (Harmer, 2010). English practical ability is included in the University English Curriculum Teaching Requirements released by National Education Department of China in 2007 (Wen, 2013). It serves as a guidance to improve students' comprehensive ability of a foreign language, helping them to build up the habit of thinking in English and promoting them to improve their abilities in writing, listening, speaking, reading and translation (Zhang, 2006). However, the traditional teaching approach in most Chinese colleges mainly focuses on the writing skills alone and pays too much attention to the theoretical knowledge, leading to the separation of the language learning and practical writing in the business context (Wei, 2011). Therefore, it fails to provide learners with a real business scenario and ignores the subject itself.

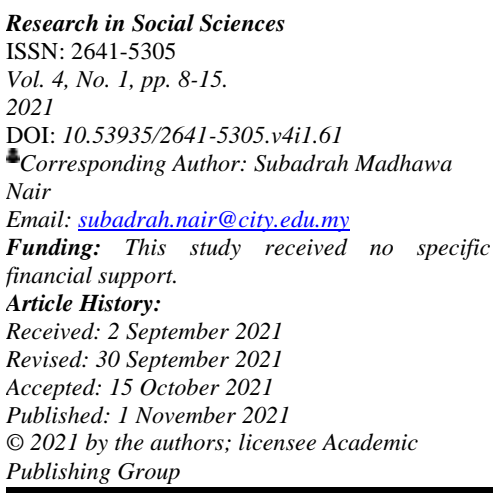


The CLIL (Content and Language Integrated Learning) aims to integrate the professional knowledge of a subject with the application of a foreign language (Marsh, Maljers, \& Hartiala, 2001). It is a practical teaching method in that it provides a real language learning environment while study the contents of the textbooks effectively (Coyle, 2006). The role of Business English writing is to obtain the information and deal with related matters in daily business communication. The implementation of CLIL teaching approach in Business English writing proved to be feasible to solve the existing problems of Business English Writing in terms of disconnection between the real business transactions and classroom teaching (Ting, 2010).

Currently, the conventional teaching of a foreign language in most colleges of China are focusing on memorizing words, patterns and sample essays in order to cope with the examination (Liu \& Huang, 2013). However, a language is a part of culture and the main carrier of cultural transmission. In this sense, in addition to cultivating students' communicative competence, the foreign language teaching should also enrich the cultural aspect of the target language (Cummins, 2008). The CLIL principle embraces the acquisition of the second foreign language skills while at the same time facilitates learners in practicing their communication abilities, cognitive levels, as well as the cross-cultural understanding (Lasagabaster \& Sierra, 2009).

This paper studies the effectiveness of the CLIL instruction while experimentally applies it to the teaching of Business English memo, report and letter writing, hoping to provide a feasible solution to the current fixed pattern of Business English writing in China and also aims to explore the challenges faced by teachers in adopting the CLIL method in colleges.

\subsection{Research Hypothesis}

Three null hypothesis were formulated as follow:

Hol. There is no significant difference in the mean scores for Business English memo writing between the Experimental Group (CLIL method) and the Control Group (conventional method).

Ho2. There is no significant difference in the mean scores for Business English report writing between the Experimental Group (CLIL method) and the Control Group (conventional method).

Ho3. There is no significant difference in the mean scores for Business English letter writing between the Experimental Group (CLIL method) and the Control Group (conventional method).

Ho4. There is no significant difference in the mean scores for the overall achievement for Business English Writing between the Experimental Group (CLIL method) and the Control Group (conventional method).

\section{Literature Rreview}

The CLIL method broadly refers to any teaching environment that achieves the dual purpose of language and subject knowledge learning (Ioannou, 2012). In such an environment, one or more foreign languages are taught in the subjects as the medium of learning. The content includes not only subject knowledge, but also topics that students are interested in.

Business English Writing is a professional and compulsory course for Business English majors in Chinese colleges (Ge, 2013; Wang, 2019). It integrates writing theory with practice and develops students' writing proficiency to the levels that are required by higher-level business positions (Dong, 2016). By presentation and analysis of representative model, the CLIL method deepens students' understanding of a variety of common business documents, such as business letters, memos, minutes, company profiles, business reports, business plans, annual reports and contracts (Maican, 2020; Martyn, 2018). It gives students a grasp of pragmatic functions related to business documents and later provides training in how to write and modify corresponding files based on simulated business situations which helps to expand students' business vocabulary (Léon-Henri., 2015). With the help of CLIL method, students will develop a sense of team spirit in a collaborative learning environment and therefore require proficient practical writing skills (Pengnate, 2013).

In the early 1990s, under the promotion of the multilingualism policy pursued by the European Union, the concept of CLIL emerged and developed rapidly in Europe. In 1994, the European Union White Paper formally proposed the unified use of the term Content and Language Integrated Learning (Dalton-Puffer, 2008). The ultimate goal is to encourage European citizens learn to use "Mother Tongue +2" (i.e. mother tongue plus two foreign languages), which is essentially a reflection of the EU's political requirements for building a harmonious multicultural and multilingual society in language education (Dalton-Puffer., Nikula, \& Smit, 2010). Another driving force for the widespread promotion of CLIL originates from the globalized education. Dalton-Puffer (2008) pointed out that with the diversification and inclusiveness of different 
languages and cultures, it is necessary for the existing education system to change the traditional singlelanguage teaching model while develop a mode that can effectively seek to train students' multiple literacy abilities so as to address the challenges of the globalized community.

Language serves as an important tool of learning professional business knowledge. As CLIL principle focuses on the language itself, it greatly facilitate students' output in a business context in terms of report and letter writing (Léon-Henri, 2014). Therefore, students will be able to put their language knowledge in practice which serves as a strong motivation in future learning. CLIL mode integrates content and language, uses content as a carrier, as well as pays attention to students' verbal abilities in terms of vocabulary, grammar, and pronunciation. The CLIL approach as a medium of knowledge not only promotes the effective learning of a professional subject, but at helps to improve their business writing abilities (Moore \& Lorenzo, 2007). In college English writing, CLIL not only offers a real scenario for students, but also helps them to effectively use the English language which provides solutions for the current writing problems of disjunction between the current old-fashioned English teaching mode and the market demand in today's globalized world (Guo \& Wu, 2013).

CLIL helps to cultivate students' cross-cultural communication skills and strengthen their learning motivation (Sudhoff, 2010). Further, it also improves their initiative in learning and improve their professional knowledge. Jarvinen (2009) stated that the CLIL teaching model provides students with a context with functional visibility, which helps them to interact with the content of learning through their own dynamic cognitive mechanisms to stimulate their motivation so as to complete the learning process. In addition, Grabe and Kaplan (1996) emphasized that the context of a certain theme would influence students' cognitive development and performance of writing. Van de Craen, Mondt, Allain, and Gao (2008) believed that the CLIL way of teaching motivates students to become even more engaged in cognitive activities in the learning process and improves their overall performance in all respects. CLIL can cultivate learners' self-confidence and improve their cognitive level as well as communication skills. Further, CLIL improves students' crosscultural understanding and allows them to get more involved in the learning of the target language so that they can acquire a wider and varied vocabulary and thus become more proficient in Business English writing (Louhiala-Salminen \& Kankaanranta, 2011). Mehisto, Frigols, and Marsh (2008) noted that the CLIL teaching model is characterized by four elements, respectively, culture, environment, language, and content learning. Based on that theory, Coyle (2006) initiated a 4Cs system framework for CLIL's curriculum, namely, content, cognition, communication, and culture. To begin with, the content not only refers to the acquired knowledge and skills, but also includes learners to improve their own understanding and learning skills. Secondly, the cognition is closely correlated with the thinking abilities so that the learners should deepen their understanding of the contents by analyzing the tasks in the classroom and then reconstructing the corresponding cognitive process. Thirdly, communication refers to the interactivity of the learning context, which is crucial in the learning process. Finally, culture means the cross-cultural awareness towards different foreign languages. The purpose of communication is achieved based on cross-cultural awareness. They are independent but complementary to each other, forming an organic unity of content learning and language learning.

Coyle (2006) believed that subject learning not only includes the acquisition of knowledge and skills, but also involves the process of constructing learners' cognition. The understanding of subject knowledge and skills is inseparable from cognition. Language must be acquired in a certain communicative environment, and subject knowledge can be constructed through language learning content. CLIL provides learners with a broader cultural context, helps students builds cross-cultural knowledge and develops their communication skills. Business English Writing is a professional and compulsory course for Business English majors in Chinese colleges (Ge, 2013; Wang, 2019). It integrates writing theory with practice and develops students' writing proficiency to the levels that are required by higher-level business positions (Dong, 2016). By presentation and analysis of representative model, the CLIL method deepens students' understanding of a variety of common business documents, such as business letters, memos, minutes, company profiles, business reports, business plans, annual reports and contracts (Maican, 2020; Martyn, 2018). It gives students a grasp of pragmatic functions related to business documents and later provides training in how to write and modify corresponding files based on simulated business situations which helps to expand students' business vocabulary (Léon-Henri., 2015). With the help of CLIL method, students will develop a sense of team spirit in a collaborative learning environment and therefore require proficient practical writing skills (Pengnate, 2013).

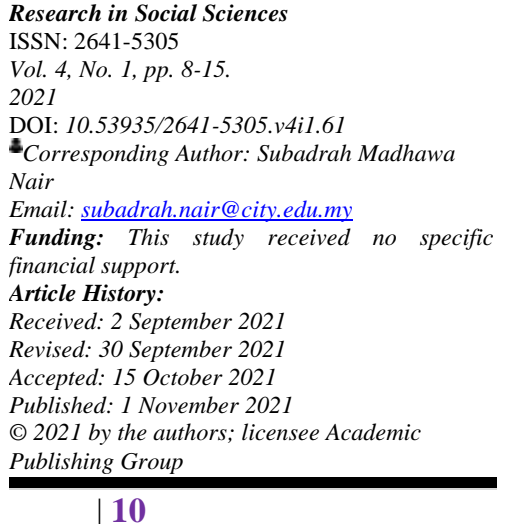




\section{Methodology}

This is a quantitative study which applies a quasi-experimental design. There are two groups, the Experimental Group and the Control Group which adopted CLIL method and conventional method respectively. The sample of the study are 80 third-year Business English majors from Shaoyang University, Hunan province, China. This college has a population of 511 Business English students in total. These 80 participants come from two classes as an intact group. Further, both classes are taught by two different English teachers with eight years of teaching experience. This experiment lasted for 8 weeks, 4 hours for each week, that is a total of 32 hours. According to the previous test data, the average level of English writing in these two classes is about the same. Before the intervention a pre-test was administered and then a post-test was carried out afterwards. The content of both the tests are the same which consist of memo writing (20 marks), report writing (40 marks), and letter writing (40 marks), that is 100 marks in total. The quantitative data was collected through a pre-test and post-test.

\section{Data Analysis and Results}

Hol. There is no significant difference in the mean scores for Business English memo writing between the Experimental Group (CLIL method) and the Control Group (conventional method).

\begin{tabular}{cccccccc}
\multicolumn{8}{c}{ Table-1a. Comparison of Memo Writing for Business English Writing (Pre-test). } \\
\hline Group & N & Mean & Std. Deviation & Mean Difference & t-value & df & p-value \\
\hline Exp. Group & 40 & 15.22 & 1.804 & -0.100 & -0.281 & 78 & 0.780 \\
Con. Group & 40 & 15.32 & 1.347 & & & & \\
\hline Note: Level of significance is at $\mathrm{p}<0.05$ & & & & &
\end{tabular}

Table 1a displays the students' mean scores for Business English memo writing before the intervention. The mean score of the Experimental Group was 15.22 while the Control Group was 15.32. The results from the independent-samples t-test show that there was no significant difference between the mean scores of students of the experimental and control groups for their performance in Business English memo writing prior to intervention (Mean difference $=-.100, \mathrm{t}=-.281, \mathrm{df}=78, \mathrm{p}=.780$ ).

Table-1b. Comparison of Memo Writing for Business English Writing (Post-test).

\begin{tabular}{cccccccc}
\multicolumn{8}{c}{ Table-1b. Comparison of Memo Writing for Business English Writing (Post-test). } \\
\hline Group & $\mathbf{N}$ & Mean & Std. Deviation & Mean Difference & t-value & df & p-value \\
\hline Exp. Group & 40 & 16.72 & 1.012 & 1.250 & 4.298 & 78 & 0.000 \\
Con. Group & 40 & 15.47 & 1.535 & & & \\
\hline Note: Level of significance is at $\mathrm{p}<0.05$.
\end{tabular}

Table 1b shows the students' mean scores for Business English memo writing after the intervention. The mean score for the Experimental Group was 16.72 while the data for the Control Group was 15.47. The results from the independent-samples t-test revealed that there was significant difference between the mean scores of students of the experimental as well as control groups for their performance in Business English memo writing skills after the intervention (Mean difference $=1.250, \mathrm{t}=4.298 \mathrm{df}=78, \mathrm{p}=.000$ ). Therefore, the results failed to accept Ho1. The findings in Table 1b show that the utilization of CLIL method in teaching Business English memo writing realized a significant progress in the Experimental Group.

Ho2. There is no significant difference in the mean scores for Business English report writing between the Experimental Group (CLIL method) and the Control Group (conventional method).

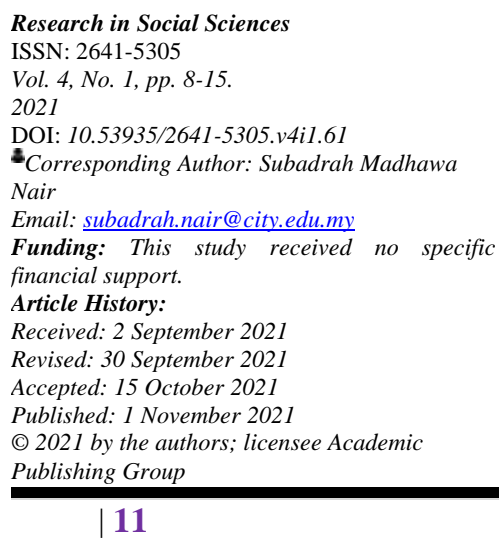

Table-2a.Comparison of Report Scores for Business English Writing (Pre-test).

\begin{tabular}{cccccccc}
\hline Group & N & Mean & Std. Deviation & Mean Difference & t-value & df & p-value \\
\hline Exp. Group & 40 & 28.45 & 2.123 & -0.175 & -0.271 & 78 & 0.787 \\
Con. Group & 40 & 28.62 & 3.483 & & & & \\
\hline Note: Level of significance is at $<<0.05$ & & & &
\end{tabular}

Table 2a illustrates the students' mean scores for Business English report writing prior to intervention. The mean score of the Experimental Group was 28.45 while as for the Control Group the data was 28.62. The results from the independent-samples t-test show that there was no significant difference between the 
experimental as well as the control groups in their mean scores for report writing before the intervention (Mean difference $=-.175, \mathrm{t}=-.271, \mathrm{df}=78, \mathrm{p}=.787$ ).

\begin{tabular}{cccccccc}
\multicolumn{7}{c}{ Table-2b. Comparison of Report Scores for Business English Writing (Post-test). } \\
\hline Group & N & Mean & Std. Deviation & Mean Difference & t-value & df & p-value \\
\hline Exp. Group & 40 & 32.67 & 2.246 & 2.950 & 5.106 & 78 & 0.000 \\
Con. Group & 40 & 29.72 & 2.882 & & & & \\
\hline Note: Level of significance is at $p<0.05$ & & & &
\end{tabular}

Table $2 \mathrm{~b}$ showcases the students' mean scores for Business English report writing skills after the intervention. The mean score for the Experimental Group was 32.67 which was higher than the Control Group (Mean=29.72). The results from the Independent-samples t-test revealed that the experimental performed significantly higher than the control groups in Business English report writing skills after the intervention (Mean difference $=2.950, \mathrm{t}=5.106, \mathrm{df}=78, \mathrm{p}=.000$ ). Therefore, the results failed to accept Ho2. The findings in Table $1 \mathrm{~b}$ show that the utilization of CLIL method in teaching Business English report writing was very effective and the students in the Experimental Group realized an improvement in the report writing.

Ho3. There is no significant difference in the mean scores for Business English letter writing between the Experimental Group (CLIL method) and the Control Group (conventional method).

\begin{tabular}{cccccccc}
\multicolumn{8}{c}{ Table-3a. Comparison of Letter Scores for Business English Writing (Pre-test). } \\
\hline Group & N & Mean & Std.Deviation & Mean Difference & t-value & df & p-value \\
\hline Exp. Group & 40 & 30.25 & 2.415 & -0.325 & -0.558 & 78 & 0.578 \\
Con. Group & 40 & 30.57 & 2.781 & & & & \\
\hline Note: Level of significance is at $\mathrm{p}<0.05$. & & & &
\end{tabular}

Table 3a indicates the students' mean scores for Business English letter writing prior to intervention. The mean score of the Experimental Group was 30.25. On the other hand, the data for the Control Group was 30.57. The results from the Independent-samples t-test show that there was no significant difference between the mean scores of students of the experimental as well as control groups for their performance in Business English letter writing before the intervention (Mean difference $=-.325, \mathrm{t}=-.558, \mathrm{df}=78, \mathrm{p}=.578$ ).

\begin{tabular}{cccccc|cc}
\multicolumn{8}{c}{ Table-3b. Comparison of Letter Scores for Business English Writing (Post-test). } \\
\hline Group & N & Mean & Std. Deviation & Mean Difference & t-value & df & p-value \\
\hline Exp. Group & 40 & 33.05 & 1.934 & 1.700 & 3.771 & 78 & 0.000 \\
Con. Group & 40 & 31.35 & 2.094 & & & & \\
\hline Note: Level of significance is at $<<0.05$ & & & &
\end{tabular}

Table 3b reveals the students' mean scores for Business English letter writing after the intervention. The mean score for the Experimental Group was 33.05. However, the Control Group was 31.35. The results from the Independent-samples t-test revealed that there was significant difference between the mean scores of students of the experimental as well as control groups for their performance in Business English letter writing skills after the intervention (Mean difference $=1.700, \mathrm{t}=3.771, \mathrm{df}=78, \mathrm{p}=.000$ ). Therefore, the results failed to accept Ho3. The findings in Table $3 \mathrm{~b}$ show that the utilization of CLIL method in teaching Business English letter writing is more effective.

Ho4. There is no significant difference in the mean scores for the overall achievement for Business English Writing between the Experimental Group (CLIL method) and the Control Group (conventional method).

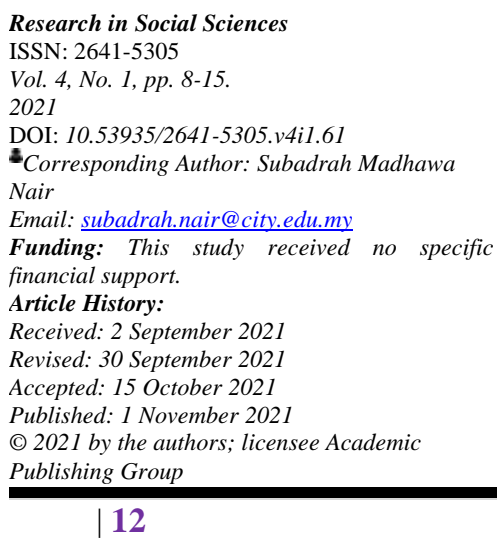

\begin{tabular}{cccccccc}
\multicolumn{7}{c}{ Table-4a. Comparison of Overall Mean Scores for Business English Writing (Pre-test). } \\
\hline Group & N & Mean & Std. Deviation & Mean Difference & t-value & df & p-value \\
\hline Exp. Group & 40 & 73.92 & 4.028 & -0.525 & -0.508 & 78 & 0.613 \\
Con. Group & 40 & 74.45 & 5.153 & & & & \\
\hline
\end{tabular}

Table 4a indicates the students' overall mean scores for Business English Writing prior to intervention. The overall mean score of the Experimental Group was 73.92. On the other hand, the data for the Control 
Group was 74.45. The results from the Independent-samples t-test show that there was no significant difference between the overall mean scores of students of the experimental as well as control groups for their performance in Business English Writing prior to intervention (Mean difference $=-.525, \mathrm{t}=-.508, \mathrm{df}=78, \mathrm{p}=$ $.613)$.

Table-4b. Comparison of Overall Mean Scores for Business English Writing (Post-test).

\begin{tabular}{cccccccc}
\hline Group & N & Mean & Std. Deviation & Mean Difference & t-value & df & p-value \\
\hline Exp. Group & 40 & 82.45 & 3.456 & 5.900 & 7.206 & 78 & 0.000 \\
Con. Group & 40 & 76.55 & 3.856 & & & & \\
\hline Note: Level of significance is at $\mathrm{p}<0.05$. & & & & &
\end{tabular}

Table $4 \mathrm{~b}$ indicates the students' overall mean scores for Business English Writing after the intervention. The overall mean score for the Experimental Group was 82.45. Whereas the overall mean scores for the Control Group was 76.55. The results from the Independent-samples t-test revealed that there was significant difference between the overall mean scores of students of the experimental as well as control groups for their performance in Business English letter writing skills after the intervention (Mean difference $=5.900, t=7.206$, $\mathrm{df}=78, \mathrm{p}=.000)$. Therefore, the results failed to accept Ho4. The findings in Table $3 \mathrm{~b}$ show that the utilization of CLIL method in teaching Business English Writing has greatly improved students' overall performance as compared with their counterparts who were instructed under the conventional method.

\section{Discussions}

The findings in Table 1b were consistent with findings by Moore and Lorenzo (2007); Léon-Henri. (2015), as well as Van de Craen et al. (2008) who stressed that the CLIL method was helpful in facilitating students' writing skills because the students were more confident and exposed to professional business vocabulary. The findings in Table $2 b$ were parallel with findings by Louhiala-Salminen and Kankaanranta (2011) and Léon-Henri (2014) which indicated that when students immersed in the CLIL environment they performed better than those who were taught using conventional strategies. In addition, students from the experimental group were more proficient in English because they learned the subject in a real business context. The findings in Table 3b were supported by Sudhoff (2010); Martyn (2018) as well as Maican (2020) which indicated that the CLIL students improved greatly not only in second language acquisition, but also performed satisfactorily in Business English letter writing because the students learned about the cultural aspects and therefore were more motivated and engaged in the class. The findings in Table $4 \mathrm{~b}$ were in line with the findings of Dalton-Puffer (2008); Mehisto et al. (2008) as well as Pengnate (2013) which showed that the overall performance of CLIL group of students were proved to be significantly better than the conventional group because the students were more proficient in English and learned the authentic expressions in a real business scenario with a sense of collaborative spirit.

In a word, the data illustrated that the CLIL approach significantly improved students' Business English memo, report and letter writing proficiency. This mode integrates the knowledge in writing and the context of global business which are more specific and real. At the same time, students' horizons are broadened, their cross-cultural awareness and ability are enhanced to a large extent. Therefore, their cognition level has been significantly improved and their language ability has been promoted. In general, students' learning motivation and their mastery of writing skills were improved greatly. During the learning process, their cultural awareness and cross-cultural communication skills are prepared for the ongoing internationalization.

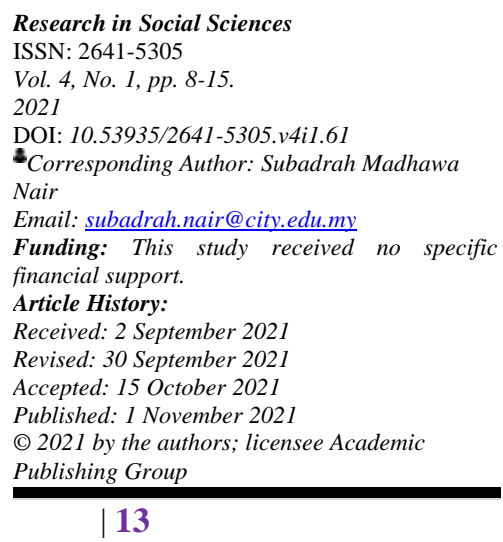

\section{Conclusions, Implications and Recommendations}

The findings of the quantitative data of the this study indicated that students immersed in the CLIL environment performed better than their counterparts who taught with the conventional method in terms of Business English memo, report and letter writing, as well as their overall performance.

This study also illustrated some significant findings which have pedagogical, theoretical, and practical implications. In term of pedagogical enlightenment, the CLIL method helped the teacher to arouse students' interest in Business English Writing using CLIL's curriculum, which was designed in line with Coyle (2006) 4Cs framework, respectively, content, cognition, communication, and culture (Cross, 2016). In terms of the theoretical implications, teachers should come up with more innovative ways to further improve the CLIL 
method because this approach is not widely accepted among Chinese colleges so that more efforts should be put in this respect. In terms of practical aspect, students in the CLIL classroom learned practical Business English Writing skills which helps them to communicate or interact with their business partners more effectively in the future workplace. Further, under the guidance of CLIL principle, teachers would be able to expand students' reservoir of business vocabulary, the variety of sentence patterns, and their tolerance of culture diversity.

However, there are still limitations in this study. First of all, as CLIL was originated in Europe, it only began to take roots in China in recent decades so that the government failed to pay sufficient attention in promoting this innovative teaching method. Only with the support of the local authority can the research be carried out more smoothly. Second, it is important that teachers should receive an adequate training on how to employ the CLIL strategy to teach other English subjects. When using this model, it should be improved according to the specific situation of the college students in China. Finally, the sample size of this study only consists of 80 third year college students from a southern part of Chinese university. As such, it is hoped that future studies should involve a larger sample, for example, from the inland regions or the economic developed areas because the education level vary greatly in different parts of China. In addition, as this study only analyzed one course of Business English Writing, it is suggested that future researches may focus on other English subjects, such as Business English Reading, Business English Translation, Business English Listening or some second foreign language contents so as to prove the feasibility of the CLIL instruction in all respects.

\section{References}

Andon, N., \& O'Riordan, S. (2004). Teach yourself english for international business. London: Hodder Arnold.

Coyle, D. (2006). Content and language integrated learning: Towards a connected research agenda for CLIL pedagogies. International Journal of Bilingual Education and Bilingualism, 10(5), 543-562. Available at: https://doi.org/10.2167/beb459.0.

Cross, R. (2016). Language and content 'integration': The affordances of additional languages as a tool within a single curriculum space. Journal of Curriculum Studies, 48(3), 388-408. Available at: https://doi.org/10.1080/00220272.2015.1125528.

Cummins, J. (2008). Teaching for transfer: Challenging the two solitudes assumption in bilingual education. In J. Cummins \& N. H. Hornberger (Eds.), Encyclopedia of Language and Education (2nd ed., pp. 35-75). New York: Springer.

Dalton-Puffer, C. (2008). Outcomes and processes in content and language integrated learning (CLIL): Current research from Europe. In W. Delanoy \& L. Volkmann (Eds.), Future perspectives for English language teaching (pp. 139-157). Heidelberg: Carl Winter.

Dalton-Puffer., C., Nikula, T., \& Smit, U. (2010). Language use and language learning in CLIL classrooms. Amsterdam: John Benjamins.

Dong, X. (2016). Business English writing (2nd ed.). Beijing: University of International Business and Economics Press.

Ge, C. (2013). The writing of English. Shanghai: Shanghai Translation Publishing House.

Grabe, W., \& Kaplan, R. B. (1996). Theory and practice of writing: An applied linguistic perspective. London and New York: Longman.

Guo, Y. Q., \& Wu, X. J. (2013). On the application of CLIL in college English writing. Foreign Language and Literature, 29(2), 166169. Available at: https://doi.org/10.2307/374047.

Harmer, J. (2010). The practice of English language teaching. New York: Longman Group.

Ioannou, G. S. (2012). Reviewing the puzzle of CLIL. ELT Journal, 66(4), 495-504. Available at: https://doi.org/10.1093/elt/ccs047.

Jarvinen, H. M. (2009). What has ecology to do with CLIL? An ecological approach in Content and Language Integrated Learning. In Marsh et al (Eds.) CLIL Practice: Perspectives from the Field. Finland: University of Jyväskylä.

Lasagabaster, D., \& Sierra, J. M. (2009). Language attitudes in CLIL and traditional EFL classes. International CLIL Research Journal, 1(2), 4-17.

Léon-Henri, D. D. P. (2014). Breaking the ice with Business English. The Journal of Teaching English for Specific and Academic Purpose, 2(3), 345-358.

Léon-Henri., D. D. P. (2015). CLIL in the business English classroom: From language learning to the development of professional communication and metacognitive skills. ELT World Online (Special Issue on CLIL), 4, 1-26.

Liu, H. Y., \& Huang, F. Q. (2013). On the background, perspectives and implications of content and language Integrated learning. Journal of Guangdong University of Foreign Studies, 9(5), 87-100.

Louhiala-Salminen, L., \& Kankaanranta, A. (2011). Professional communication in a global business context: The notion of global communicative competence. IEEE Transactions on Professional Communication, 54(3), 244-262. Available at: https://doi.org/10.1109/tpc.2011.2161844.

Maican, M. A. (2020). Benefits of applying the CLIL conceptual framework in Business English classes. Bulletin of the Transilvania University of Brasov, 13(62), 190-198. Available at: https://doi.org/10.31926/but.es.2020.13.62.2.20.

Marsh, D., Maljers, A., \& Hartiala, A. K. (2001). Profiling European CLIL classrooms: Languages open doors. Finland: University of Jyväskylä.

Martyn, E. R. (2018). Integrating content and language in Business English teaching in China: First year students' perceptions and learning experience. English Language Teaching, 11(8), 86-102. Available at: https://doi.org/10.5539/elt.v11n8p86.

Mehisto, P., Frigols, M. J., \& Marsh, D. (2008). Uncovering CLIL: Content and language integrated learning and multilingual education. London: Macmillan. 
Moore, P., \& Lorenzo, F. (2007). Adapting authentic materials for CLIL classrooms. CLIL, 16(3), 28-35.

Pavlenko, A., \& Norton, B. (2007). Imagined communities, identity, and English language teaching. In J. Cummins \& C. Davison (Eds.), International Handbook of English Language Teaching (pp. 669-680). New York: Springer.

Pengnate, W. (2013). Ways to develop English proficiency of business students: Implementation of content and Language Integrated Learning (CLIL) approach. International Journal of Education and Research, 1(8), 1-12.

Sudhoff, J. (2010). CLIL and intercultural communicative competence: Foundations and approaches towards a fusion. International CLIL Research Journal, 1(3), 30-37.

Ting, T. Y. (2010). CLIL appeals to how the brain likes its information: Examples from CLIL-neuro science. International CLIL Research Journal, 1(3), 3-18.

Van de Craen, P., Mondt, K., Allain, L., \& Gao, Y. (2008). Why and how CLIL works? Vienna English Working Papers, 8(16), 132153.

Wang, M. X. (2019). Teaching practice of talents training for Business English students. Journal of Jilin Radio and TV University, 4(28), 36-37.

Wei, R. (2011). Parental support for Chinese-English bilingual education: A survey of parents of primary and secondary students in Shanghai. Journal of Multilingual and Multicultural Development, 32(5), 481-496. Available at: https://doi.org/10.1080/01434632.2011.592588.

Wen, Q. F. (2012). Teaching English as an international language in China. English Education, 6(13), 79-93.

Wen, Q. F. (2013). English as a lingua franca: A pedagogical perspective. Journal of English as a Lingua Franca, 1(2), $371-376$.

Zhang, X. M. (2006). Survey on the current teaching method of college English. Foreign Language World, 6(5), 28-32.

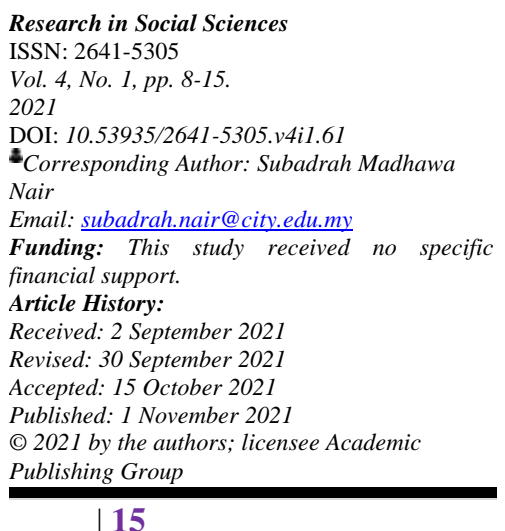

